\title{
PEMANFAATAN APLIKASI CANVA DALAM PROSES PEMBELAJARAN BAHASA ARAB DI MAN GUNUNG PADANG PANJANG
}

\author{
Amrina $^{1}$, Adam Mudinillah ${ }^{2}$, Ega Putri Handayani ${ }^{3}$ \\ ${ }^{1}$ Institut Agama Islam Negeri Batusangkar, Sumatera Barat, Indonesia \\ ${ }^{2}$ Sekolah Tinggi Agama Islam Al-Hikmah Pariangan Batusangkar, Sumatera Barat, Indonesia \\ ${ }^{2}$ Institut Agama Islam Negeri Batusangkar, Sumatera Barat, Indonesia \\ Email: amrina@iainbatusangkar.ac.id ${ }^{1}$, adammudinillah@staialhikmahpariangan.ac.id², \\ egaputri157@gmail.com ${ }^{3}$
}

\begin{tabular}{l|l|l} 
Received: Oktober 2021 & Accepted: Desember 2021 & Published: Desember 2021
\end{tabular}

\begin{abstract}
This article examines the use of Canva software in the Arabic learning process. Canva is a graphic design application that helps users to more easily design various types of creativity from the inspiration of their own thoughts. In the learning process, this software is indispensable. This software arose from the thought of designing tools that help produce work in learning, and can be done anywhere. This is of course in line with the learning needs during the COVID-19 virus pandemic, where the government prefers to carry out activities at home. The subject of the research is a teacher who has teaching experience in class XI MAN Gunung Padang Panjang. Research is directed at describing the steps, features and benefits of learning to use Canva. The results of the study found that teachers followed a step-by-step tutorial to use Canva which has various features, so that users can use it to produce a work in the form of a poster. Teachers feel the benefits of using Canva more towards graphic design in learning. Not only learning languages, Canva is proven to encourage students' creativity.
\end{abstract}

Keywords: arabic learning, canva features, learning technology

\begin{abstract}
Abstrak: Artikel ini mengkaji tentang pemanfaatan software Canva pada proses pembelajaran bahasa Arab. Canva merupakan aplikasi desain grafis yg membantu penggunanya supaya lebih simpel merancang aneka macam jenis kreatifitas dari inspirasi pemikiran sendiri. Dalam proses pembelajaran, software ini sangat diperlukan. Software ini muncul dari pemikiran untuk merancang alat yang membantu menghasilkan karya dalam pembelajaran, dan dapat dilakukan di mana saja. Hal ini tentu sejalan dengan kebutuhan pembelajaran saat pandemi virus COVID19, di mana pemerintah lebih menyarankan untuk melakukan kegiatan di rumah. Subjek dari penelitian adalah guru yang memiliki pengalaman mengajar di kelas XI MAN Gunung Padang Panjang. Penelitian diarahkan pada upaya mendeskripsikan langkah-langkah, fitur serta manfaat dari pembelajaran menggunakan Canva. Hasil penelitian mendapati bahwa guru mengikuti tutorial langkah-langkah untuk menggunakan Canva yang memiliki fitur beragam, sehingga dapat dimanfaatkan oleh pengguna untuk menghasilkan sebuah karya berbentuk poster. Guru merasakan manfaat dari penggunaan Canva ini lebih ke arah desain grafis dalam pembelajaran. Tidak hanya belajar bahasa, Canva terbukti dapat mendorong munculnya kreativitas siswa.
\end{abstract}

Kata Kunci: pembelajaran bahasa Arab, Fitur Canva, teknologi pembelajaran 


\section{A. Pendahuluan}

Menyebarnya kasus Corona Virus atau disebut dengan COVID-19 yang begitu cepat di indonesia dan di global sangat memprihatinkan serta memberi akibat pada semua sektor kehidupan terutama di bidang pengetahuan. Pemerintah menindak lanjuti yang harus dilakukan masyarakat yaitu dengan menjaga protokol kesehatan di sekitar lingkungan tempat tinggal masingmasing. Quality pengetahuan sangat menantang di tengah maraknya kasus ini. Kementerian Pendidikan ikut menginformasikan untuk diterapkannya pengajaran daring agar ketertiban masyarakat terhadap menjaga protokol kesehatan antara sesama. Dengan keluarnya Surat Edaran Nomor 4 Tahun 2020 perihal dilakukannya Kebijakan Pendidikan dalam masa darurat penyebaran kasus COVID-19. Mentri Pendidikan dan Kebudayaan menginformasikan supaya seluruh instansi pendidikan tdk mengerjakan pengajaran secara eksklusif, tetapi dilakukan proses pengajaran tersebut dengan cara jarak jauh atau daring. ${ }^{1}$

Belajar adalah proses dimana tingkah laku ditimbulkan melalui praktek atau latihan pada kehidupan sehari-hari. Belajar juga identik menggunakan sekolah, dimana disekolah kita mampu mengetahui hal-hal baru yang belum pernah dipelajari pada lingkungan luar. Namun, dimasa sekarang kita tidak bisa belajar di sekolah dikarenakan makin marak nya perkara penyebaran virus COVID-19 tahun ini.2 Akibat dari COVID-19 ini selain menghambat pembelajaran tatap muka di sekolah juga menghambat perekonomian rakyat di sekitar, menjatuhkan nilai tukar rupiah, harga barang naik, termasuk alat-alat medis pada rumah sakit atau puskesmas terdekat di kampungkampung kecil. Akibat lain dari pandemi ini juga memicu kepada perubahan sikap yg bersifat luas dan pada jangka waktu yang panjang. Perubahan sikap tersebut mencakup sikap menggunakan teknologi, sikap kerja, sikap dalam pendidikan, sikap memakai media sosial, dan sikap sosial keagamaan. ${ }^{3}$ Perubahan sikap pada pembelajaran disebabkan karena interaksi di sekitar. Interaksi ini biasanya terjadi dengan sengaja. Hal tersebut terlihat dalam faktor berikut, yaitu: (1) Persiapan Diri yaitu berhubungan dengan fisik atau mental yang berada dalam diri terkhusus dalam hal pembelajaran; (2) Motivasi yaitu dukungan dari diri sendiri dan lingkungan sekitar; (3) Capaian Tujuan. ${ }^{4}$

\footnotetext{
${ }^{1}$ Lita Izzatunnisa et al., "Motivasi Belajar Siswa Selama Pandemi Dalam Proses Belajar Dari Rumah," Jurnal Pendidikan 9, no. 2 (2021): 7-14.

2 Muh. Sain Hanafy, "Konsep Belajar Dan Pembelajaran," Lentera Pendidikan : Jurnal Ilmu Tarbiyah Dan Keguruan 17, no. 1 (2014): 66-79, https://doi.org/10.24252/lp.2014v17n1a5.

3 Ely Satiyasih Rosali, "Aktifitas Pembelajaran Daring Pada Masa Pandemi Covid-19 Di Jurusan Pendidikan Geografi Universitas Siliwangi Tasikmalaya," Geography Science Education Journal (GEOSEE) 1, no. 1 (2020): 21-30.

4 Takdir Takdir, "Problematika Pembelajaran Bahasa Arab," Jurnal Naskhi: Jurnal Kajian Pendidikan Dan Bahasa Arab 2, no. 1 (2020): 40-58, https://doi.org/10.47435/naskhi.v2i1.290.
} 
Teknologi adalah hasil dari perkembangan ilmu pengetahuan yang terjadi di dunia pendidikan. ${ }^{5}$ Oleh sebab itu, sudah selayaknya pendidikan sendiri memanfaatkan teknologi untuk membantu pelaksanaan proses belajar mengajar. Hal tersebut dapat dinyatakan bahwa teknologi masa kini telah sangat diperlukan serta banyak dipergunakan pada masa sekarang ini sebagai sarana mempermudah proses belajar mengajar baik pada penyampaian materi dari pendidik kepada peserta didik maupun membuat karya menggunakan inspirasi inspirasi brilian yg bernilai tinggi. ${ }^{6}$ Teknologi itu sendiri hasil kreasi dari manusia, lumrah jika masih terdapat kekurangan pada teknologi tadi. Di dalam dunia pendidikan teknologi masih banyak kurang nya dari segi positif maupun segi negatif masih bisa ditemukan dalam teknologi ini. ${ }^{7}$ Penggunaan teknologi yang tadinya sering digunakan dalam hal lain diluar dalam hal pembelajaran, dimasa sekarang lebih mengedepankan teknologi sebagai media pembelajaran. Banyak teknologi dalam bentuk aplikasi yang digunakan sebagai media pembelajaran jarak jauh terutama penggunaan aplikasi Canva sebagai media pembelajaran di masa pandemi ini. ${ }^{8}$

Peningkatan kualitas pembelajaran banyak ditentukan oleh proses belajar yang telah dibuat serta dilaksanakan oleh pendidik. Pendidik sebagai ujung tombak pada pelaksanaan pendidikan terhadap pihak yang sangat berpengaruh pada proses belajar mengajar. 9 Pendidik mempunyai peranan penting pada dunia pendidikan apalagi di masa pandemi ini, pendidik harus lebih cerdas menyampaikan pengajaran atau penerangan materi pada peserta didik nya menggunakan software terbatas serta dengan waktu terbatas, dan mampu menjelaskan menggunakan cara yg tidak membuat peserta didik nya bosan mendengarkan penerangan materi dari pendidik tersebut. Kiprah dan fungsi serta tanggung jawab guru pada setiap jenjang pendidikan khususnya MAN Gunung Padang Panjang dibutuhkan supaya para peserta didik nya bisa menjadi teladan yg baik bagi adik adik di bawah nya kelak.

Teknologi yang dipergunakan di masa sekarang sangat banyak atau telah berkembang pesat dikarenakan semenjak maraknya virus COVID-19 orang-orang lebih banyak memakai jaringan teknologi berbasis software, salah satunya memakai media software Canva di bidang pendidikan,

5 B Adipura, "Pengaruh Model Pembelajaran Sains-Teknologi-Masyarakat Dalam Meningkatkan Literasi Sains Dan Teknologi Ditinjau Dari Gaya Kognitif Siswa," Al-Tadzkiyyah: Jurnal Pendidikan Islam 8 (2012): 75-83.

6 Muhamad Ngafifi, "Kemajuan Teknologi Dan Pola Hidup Manusia Dalam Perspektif Sosial Budaya," Jurnal Pembangunan Pendidikan: Fondasi Dan Aplikasi 2, no. 1 (2014): 33-47, https://doi.org/10.21831/jppfa.v2i1.2616.

7 Sudarsri Lestari, "Peran Teknologi Dalam Pendidikan Di Era Globalisasi," Edureligia; Jurnal Pendidikan Agama Islam 2, no. 2 (2018): 94-100, https://doi.org/10.33650/edureligia.v2i2.459.

8 Dewi Suminar, "Penerapan Teknologi Sebagai Media Pembelajaran Pada Mata Pelajaran Sosiologi," Prosiding Seminar Nasional Pendidikan FKIP 2, no. 1 (2019): 774-83.

9 Mugirah, "Upaya Peningkatan Kualitas Pembelaiaran Di Sekolah Dasar," Jurnal Ilmiah Guru Caraka Olah Pikir Edukatif6, no. 01 (2002). 
bisnis dan penyaluran kreativitas dalam diri. ${ }^{10}$ Perkembangan teknologi sangat berkembang pesat pada era kini, hampir seluruh aktivitas atau kegiatan dilakukan dengan memakai teknologi, termasuk pada pengajaran di sekolah oleh pendidik kepada peserta didik nya. Pada era teknologi ini ditandai menggunakan kecepatan serta kemudahan untuk menerima pandangan baru dari lingkungan sekitar yg bisa di lihat secara langsung maupun mengandalkan video atau konten orang lain pada media umum. Perkembangan yg terjadi menuntut buat terciptanya pendidikan yg membentuk lulusan berkualitas dan mempunyai daya saing yang kuat pada luar sekolah nantinya.11

Berdasarkan latar belakang di atas, penelitian dimaksudkan untuk mendeskripsikan pemanfaatan teknologi pembelajaran, yaitu penggunaan software Canva dalam pembelajaran Bahasa Arab. Hasil observasi menunjukkan bahwa software ini telah dimanfaatkan oleh pendidik untuk pembelajaran di kelas IX MAN Padang Panjang. Dengan mendeskripsikan langkah-langkah, fitur dan manfaat dari software ini, diharapkan penelitian dapat memperkaya kajian dalam pemanfaatan teknologi di bidang pendidikan.

\section{B. Kajian Teori}

\section{Pentingnya Pembelajaran Bahasa Arab}

Penggunaan bahasa penting pada pembuatan konten atau karya. Bahasa adalah suatu kebutuhan dasar dan penting bagi manusia, dikarenakan bahasa ialah media untuk memberikan inspirasi inspirasi, gagasan dan pemikiran manusia pada bentuk ucapan maupun tulisan tangan yg bermaksud agar bisa dipahami oleh orang lain atau pembaca. Karena artikel ini membahas perihal bahasa arab, jadi Apa sih bahasa arab itu? Apa bahasa arab itu penting pada pembelajaran? Kenapa bahasa arab itu dipelajari? banyak pertanyan perihal belajar bahasa arab, yuk kita jawab pertanyaan tadi satu persatu menggunakan pemaham yg kita tahu selama ini perihal bahasa arab. ${ }^{12}$ Pertama Bahasa Arab itu terdapat pengertiannya dari segi bahasa, istilah dan pendapat para ulama, yg kita bahas pertama sekali dari segi bahasanya. Bahasa Arab dari segi bahasa berarti al lughah al arabiyyah; tak jarang disingkat menjadi arabi ialah diantaranya bahasa language Semit tengah, yg berada pada rumput language Semit serta bersaudara dengan language Ibrani dan bahasa bahasa Neo-Arami. ${ }^{13}$

\footnotetext{
10 Unik Hanifah Salsabila et al., "Peran Teknologi Dalam Pembelajaran Di Masa Pandemi Covid-19," AlMutharahah: Jurnal Penelitian Dan Kajian Sosial Keagamaan 17, no. 2 (2020): 188-98, https://doi.org/10.46781/al-mutharahah.v17i2.138.

${ }^{11}$ Lailatul Hijrah et al., "Pelatihan Penggunaan Canva Bagi Siswa Di Samarinda" 3, no. 1 (2021): 98106.

12 Ambo Pera Aprizal, "Urgensi Pembelajaran Bahasa Arab Dalam Pendidikan Islam," Jurnal Pendidikan Guru 2, no. 2 (2021): 39-56, https://doi.org/10.47783/jurpendigu.v2i2.232. PRISMA, 2011).

13 Ahmad Muradi, Bahasa Arab Dan Pembelajarannya Ditinjau Dari Berbagai Aspek (PUSTAKA
} 
Secara istilah bahasa arab bisa di artikan menjadi bahasa yg digunakan oleh sekelompok manusia yang bertempat tinggal pada Negeri Gurun Sahara Jazirah Arabia. Bahasa Arab ialah Semitik rumpun bahasa Afro-Asiatik dan berkerabat dengan bahasa Ibrani dan bahasa bahasa Neo Arami yg sudah di gunakan di Jazirah Arab sejak berabad abad. Pendapat para ahli tentang pengertian bahasa arab yaitu, menurut Al-Ghalayin, bahasa arab adalah kalimat - kalimat yg dipergunakan orang arab buat mengatakan tujuan (pikiran serta perasaan ) mereka. ${ }^{14}$

Pertanyaan kedua yaitu tentang pentingnya bahasa arab, Mengapa belajar bahasa arab sangat penting? sebab bahasa arab memiliki kedudukan yang penting serta spesifik diantara bahasa - bahasa lain di dunia. Di zaman sekarang ini eksistensi bahasa arab semakin penting dikarenakan :

a. Bahasa Arab sebagai Al-Quran, maka setiap muslim yg ingin menelaah Al-Quran wajib menguasai bahasa arab.

b. Bahasa Arab sebagai bacaan pada sholat, setiap muslim dalam melaksanakan sholat wajib menggunakan bacaan arab. Dikarenakan bahasa arab sebagai peranan penting dalam agama islam.

c. Merupakan Bahasa Hadits, Hadist - hadist Nabi tersusun dengan memakai bahasa arab yang rapi serta jelas dan terpercaya kebenarannya.

\section{Media pembelajaran Bahasa Arab dengan memakai software Canva}

Kebijakan physical distancing maupun sosial distancing buat mengurangi penyebaran virus COVID-19 mendorong seluruh elemen pendidikan tetap mengaktifkan pembelajaran atau proses belajar mengajar pada kelas dengan memakai software yang bisa dimanfaatkan dalam melakukan pembelajaran. Salah satunya bisa memakai software Canva menjadi media pembelajaran menggunakan jarak jauh atau di lakukan di tempat tinggal masing masing dengan mengandalkan software ini. ${ }^{15}$ Pada waktu sekarang ini penggunaan software Canva bagi pendidik sangat diperlukan, dikarenakan masa kini adalah masa perubahan yang menunjang pendidikan menggunakan berbasis teknologi seperti salah satunya dengan memakai media software Canva ini. 16

Pelajar pada saat ini lebih banyak didominasi lebih melihat materi atau mengandalkan pemahaman materi dengan melihat youtube, jurnal atau artikel-artikel di google menjadi referensi

14 Teuku Sanwil et al., Pembelajaran Bahasa Arab Untuk Siswa SD/MI (Yayasan Penerbit Muhammad Zaini, 2021).

15 Luh Devi Herliandry et al., "Pembelajaran Pada Masa Pandemi Covid-19," JTP-Jurnal Teknologi Pendidikan 22, no. 1 (2020): 65-70.

${ }_{16}$ Munir, Multimedia Konsep \& Aplikasi Dalam Pendidikan, Antimicrobial Agents and Chemotherapy, vol. 58, 2020. 
dalam menghasilkan tugas atau makalah dari pengajar di sekolah nya. Media adalah komponen alat dalam sistem pembelajaran. Dalam artian luas media berarti pemanfaatan secara maksimum seluruh komponen sistem serta sumber belajar diatas untuk mencapai tujuan pembelajaran eksklusif. ${ }^{17}$ Pembelajaran dengan menggunakan media Canva dapat memudahkan serta menghemat waktu pendidik pada penjelasan materi pembelajaran. Media Canva sangat berguna dalam penyampaian materi oleh pendidik kepada peserta didiknya karena dengan software Canva ini bisa membuat presentasi dalam bentuk animasi atau video keren dari hasil materi pembelajaran yang ingin disampaikan kepada peserta didiknya. ${ }^{18}$

Media juga dapat diartikan menjadi mediator yg dipakai orang penyebar inspirasi, sehingga gagasan itu sampai pada orang yg dituju. Media berarti pula sebagai sarana yg dianggap saluran, sebab pada semestinya media sudah memperluas dan memperpanjang kemampuan insan untuk merasakan, mendengar serta melihat dalam batas jarak dan waktu tertentu, sekarang berkat bantuan media batasan-batasan tersebut hampir tidak ada . Dari pembahasan di atas bisa diambil kesimpulan bahwa media ialah suatu alat atau sarana atau perangkat yg berfungsi sebagai mediator atau saluran atau jembatan pada aktivitas komunikasi antara komunikator dan komunikan. ${ }^{19}$

Media pembelajaran mempunyai beberapa fungsi yaitu, Pertama Fungsi Kumulatif, fungsi ini bisa memudahkan komunikasi antara penyampai pesan dengan penerima pesan, Kedua Fungsi Motivasi, fungsi ini bisa menaikkan gairah siswanya buat jadi lebih bersemangat belajar, Ketiga Fungsi Kebermaknaan, fungsi ini bisa menaikkan kemampuan peserta didik buat menganalisis serta membentuk aspek kognitif tahap tinggi. Keempat Fungsi Penyamaan Persepsi, fungsi ini diharapkan bisa menyamakan persepsi setiap peserta didik, Kelima Fungsi Individualitas, fungsi ini bisa melayani kebutuhan setiap individu yang mempunyai minat dan gaya belajar yang tidak sama. ${ }^{20}$

Media pembelajaran dianggap juga alat bantu berupa fisik maupun nonfisik yg dipergunakan menjadi mediator antara pendidik dan peserta didik untuk memahami pembelajaran yg lebih efektif dan lebih efisien. Pengembangan media pembelajaran ini juga dapat menarik minat para

17 Haryadi Mujianto, "Pemanfaatan Youtube Sebagai Media Ajar Dalam Meningkatkan Minat Dan Motivasi Belajar," Jurnal Komunikasi Hasil Pemikiran Dan Penelitian 5, no. 1 (2019): 135-59.

${ }_{18}$ Rahma Elvira Tanjung and Delsina Faiza, "Canva Sebagai Media Pembelajaran Pada Mata Pelajaran Dasar Listrik Dan Elektronika," VoteTEKNIKA: Jurnal Vocational Teknik Elektronika Dan Informatika 7, no. 2 (2019): 79-85.

${ }^{19}$ M. Miftah, "Fungsi, Dan Peran Media Pembelajaran Sebagai Upaya Peningkatan Kemampuan Belajar Siswa," Kwangsan: Jurnal Teknologi Pendidikan 1, no. 2 (2013): 95, https://doi.org/10.31800/jtp.kw.v1n2.p95--105.

20 Rizqi Ilyasa Aghni, "Fungsi Dan Jenis Media Pembelajaran Dalam Pembelajaran Akuntansi," Jurnal Pendidikan Akuntansi Indonesia 16, no. 1 (2018), https://doi.org/10.21831/jpai.v16i1.20173. 
peserta didik buat mencoba hal - hal yg telah di jelaskan pendidik sebelumnya. ${ }^{21}$ Media pembelajaran berbasis personal komputer adalah media dan sumber terbaik yang bisa dipergunakan menjadi alat komunikasi dan pembantu pada proses belajar mengajar di sekolah. Media pembelajaran bisa dikembangkan menggunakan berbasis software Canva sebab adanya teknologi komputer atau handphone yg mampu diterapkan pada proses belajar mengajar daring pada saat sekarang ini.

Dalam memahami pelajaran pendidik menyiapkan salah satu software buat memudahkannya menggambarkan pelajaran pada peserta didik yaitu dengan memakai software Canva, Canva ialah program desain online yg menyediakan bermacam peralatan seperti presentasi, resume, poster, pamflet, brosur, grafik, infografis, spanduk, penanda buku, bulletin, serta lain sebagainya yang disediakan pada software Canva. Ada jenis-jenis presentasi yg terdapat pada Canva seperti presentasi kreatif, pendidikan, usaha, periklanan, teknologi, serta lain sebagainya. Adapun kelebihan pada software Canva bisa ditinjau sebagai berikut: ${ }^{22}$

a. Memiliki beragam desain yg menarik

b. Bisa menaikkan kreatifitas pengajar serta peserta didik pada mendesain media pembelajaran karena banyak fitur yg sudah disediakan.

c. Menghemat waktu pada media pelajaran secara mudah

d. Untuk desain, tidak wajib menggunakan laptop, namun bisa dilakukan melalui handphone (gawai).

Selain kelebihan yg didapat pada software Canva ini, terdapat juga kekurangan yg fundamental yg di dapat pada software Canva ini, yaitu bila ingin memakai Canva, setiap pemakai harus memiliki paket data supaya bisa tersambung dan bisa memakai software Canva ini, selain itu juga desain yg tersaji pada software Canva ada beberapa template yg berbayar, namun hal ini tidak menjadi problem dikarenakan banyak juga template yang bagus serta gratis buat dipergunakan. Kekurangan software Canva menjadi berikut:23

a. Software Canva mengandalkan jaringan internet yang relatif serta stabil, bila mana tidak adanya internet atau kuota pada hp juga laptop yg akan dipergunakan buat software Canva, Canva tidak bisa digunakan atau mendukung pada proses mendesain .

${ }^{21}$ Heri Susanto and Helmi Akmal, Media Pembelajaran Sejarah Era Teknologi Informasi (Konsep Dasar, Prinsi Aplikatif, Dan Perancangannya) (FKIP Universitas Lambung Mangkurat, 2019).

22 Yuli Komalasari, Muhammad Muharrom, and Achmad Sumbaryadi, "Pemanfaatan Aplikasi Canva Untuk Meningkatkan Fungsionalitas Media Sosial Pada Pengurus Dan Anggota Karang Taruna Kel. Kebon Bawang Jakarta Utara," Abditeknika Jurnal Pengabdian Masyarakat 1, no. 2 (2021): 71-77.

23 Garris Pelangi, "Pemanfaatan Aplikasi Canva Sebagai Media Pembelajaran Bahasa Dan Sastra Indonesia Jenjang SMA/MA," Jurnal Sasindo UNPAM 8, no. 2 (2020): 79-96. 
b. Pada software Canva ada template, stiker, ilustrasi, font, serta lain sebagainya secara berbayar. Jadi, terdapat beberapa yang berbayar serta ada pula yg tidak. namun hal ini tidak masalah sebab ada banyak template yang menarik dan gratis buat dipergunakan.

c. Terkadang desain yg dipilih ada kesamaan desain dengan orang lain, entah itu template-nya, gambarnya, warna serta lain sebagainya.

Manfaat dari software Canva yaitu software ini berbasis teknologi, Canva menyediakan ruang belajar buat setiap pendidik dalam melakukan suatu pembelajaran dengan mengandalkan software Canva. Memanfaatkan lebih banyak template secara gratis buat menambah minat siswa dalam mengikuti proses pembelajaran. Banyak model yang bisa dipergunakan pendidik pada software Canva buat disajikan pada siswa, salah satunya template menarik buat disajikan pada bentuk Power Point. ${ }^{24}$

Faktor yang dapat menentukan hasil dari proses pembelajaran ialah penggunaan media tersebut menyatu dengan desain yang indah atau lebih bagus serta menarik karena itu lah perhatian dan pemahaman peserta didik lebih terfokus dan cepat paham dari materi yang disampaikan dengan penggunaan software ini. Dengan penjelasan ini dapat disimpulkan bahwa peserta didik akan dapat memahami materi atau pelajaran dengan baik serta cepat dari penampilan materi pada bentuk yang menarik dan tidak membuat peserta didiknya bosan karena dilengkapi juga dengan fitur animasi bergerak yang telah ditambahkan dalam penampilan materi tersebut. $^{25}$

Pemanfaatan template Power Point pada Canva tidak ditujukan buat pendidik saja, namun juga mampu buat siswa. Jika ingin menyampaikan materi yg diharuskan memakai Canva Power Point. Umumnya seorang pendidik menyediakan video menjadi model, acuan ataupun penerangan pada siswa. Menggunakan Canva pendidik juga bisa memakai template dengan warna menarik serta tambahan font lainnya buat memperindah background video di waktu ditampilkan.

\section{Metode Penelitian}

Metode ini dilakukan menggunakan metode kualitatif deskriptif. Penelitian kualitatif dipergunakan dengan merujuk pada pendapat narasumber, bahwa metode kualitatif ialah metode penelitian yg natural karena penelitiannya dilakukan di kondisi yg alami serta data yang terkumpul dianalisis secara kualitatif. Media software yang dipergunakan pada penelitian ini ialah media

${ }^{24}$ Muhammad Sholeh, Rr. Yuliana Rachmawati, and Erma Susanti, "Penggunaan Aplikasi Canva Untuk Membuat Konten Gambar Pada Media Sosial Sebagai Upaya Mempromosikan Hasil Produk Ukm," SELAPARANG Jurnal Pengabdian Masyarakat Berkemajuan 4, no. 1 (2020): 430, https://doi.org/10.31764/jpmb.v4i1.2983.

25 Nur Mila et al., "Efektivitas Pemanfaatan Canva Sebagai Media Pembelajaran Daring," Prosiding Penelitian Pendidikan Dan Pengabdian 2021 1, no. 1 (2021): 181-88. 
software Canva, dimana dengan memakai media ini bisa memudahkan pendidik memberikan materi tanpa harus bertatap muka dengan peserta didiknya. ${ }^{26}$

Jenis data yg dikumpulkan ialah jenis data primer dan sekunder. Data primer berupa wawancara dengan narasumber secara pribadi serta kalimat klasifikasi dari jawaban subjek penelitian, observasi dan dokumentasi. Sedangkan data primer berupa hasil penelitian berbagai artikel. Subjek pada penelitian ini ialah pengajar bahasa arab kelas XI MAN Gunung Padang Panjang. Teknik penelitian dilakukan secara online melalui aplikasi WhatsApp. ${ }^{27}$

Penelitian pemanfaatan aplikasi Canva ini dipergunakan untuk mengemukakan pengetahuan atau inspirasi baru yang timbul dalam pemikiran sendiri sehingga dapat di hasilkan karya atau konten yang bermanfaat bagi diri dan lingkungan sekitar khususnya di bidang pendidikan melalui pengajaran materi kepada peserta didik.28

\section{Hasil dan Pembahasan}

\section{Langkah Langkah penggunaan Aplikasi Canva}

Hasil observasi, dokumentasi dan wawancara pemanfaatan Canva dalam pembelajaran menemukan bahwa guru mengikuti tutorial untuk menggunakan software tersebut. Hasil uji coba peneliti mendapati bahwa Canva memang menyediakan tutorial yang mudah untuk membuat aneka macam konten atau presentasi secara mudah dan cepat. Tahapan yang harus dilewati ini juga diringkas oleh penelitia lain ${ }^{29}$, sehingga dapat dikemukakan langkah umum yang digunakan yaitu:

a. Memilih jenis template yang akan dipergunakan, apakah kita ingin memakai template siap gunakan atau kita juga mampu mendesain sendiri template yg diinginkan.

b. Sesudah memilih template atau gambar, selanjutnya kita bisa memakai jenis huruf (font) yg diinginkan. Pada tahap ini kita mampu menentukan jenis dan warna huruf sesuai dengan kesukaan yang kita inginkan supaya terlihat menarik.

c. Tahap ketiga pada penggunaan software Canva yaitu pengaturan warna nya. Kita mampu menentukan warna sesuai yg kita inginkan menggunakan bentuk yang sinkron atau senada menggunakan warna font atau gambar yang telah di masukkan tadi.

${ }^{26}$ Yuli Komalasari, Muhammad Muharrom, and Achmad Sumbaryadi, "Pemanfaatan Aplikasi Canva Untuk Meningkatkan Fungsionalitas Media Sosial Pada Pengurus Dan Anggota Karang Taruna Kel . Kebon Bawang" 1 (2021): 71-77.

27 Rahmatullah Rahmatullah, Inanna Inanna, and Andi Tenri Ampa, "Media Pembelajaran Audio Visual Berbasis Aplikasi Canva," Jurnal Pendidikan Ekonomi Undiksha 12, no. 2 (2020): 317-27.

${ }^{28}$ Mardiatun Husna, "Pengembangan Media Pembelajaran Audio Visual Berbasis Macromedia Flash 8 . 0 Pada Materi Sistem Gerak Manusia DI MTsS," Fakultas Tarbiyah Dan Keguruan Universitas Islam Negeri ArRaniry Darussalam,Banda Aceh, 2021, 141.

${ }^{29}$ Sholeh, Rachmawati, and Susanti, "Penggunaan Aplikasi Canva Untuk Membuat Konten Gambar Pada Media Sosial Sebagai Upaya Mempromosikan Hasil Produk Ukm." 
d. Tahap selanjutnya yaitu tahap Keempat, tahapan ini merupakan tahapan yg menarik sebab kita mampu menentukan konten gambar yang kita inginkan. Agar terlihat menarik jangan lupa untuk menentukan gambar yg mampu diilustrasikan menggunakan kata istilah yang akan dicantumkan kepada konten gambar.

e. Background pada gambar yang telah kita pilih ternyata masih mampu kita custom sesuai kebutuhan. Bila gambar yang kita gunakan telah menggunakan warna warna kontras yg terang atau mencolok, maka kita mampu memakai atau padukan menggunakan warna warna background yang lebih lembut atau lebih lunak begitupun kebalikannya.

\section{Fitur-Fitur Canva}

Canva memiliki fitur beragam yang dapat dimanfaatkan oleh pengguna untuk menghasilkan sebuah karya berbentuk poster. Berikut rincian singkat dari fitur canva yang merupakan hasil pengamatan dan dokumentasi atas praktik guru menggunakan software tersebut.

a. Template Siap Pakai

Fitur utama serta membuat jutaan orang menyukai canva ialah ketersediaan template yg sangat beragam, walaupun beberapa di antaranya berbayar. Namun, opsi gratisnya saja sudah lebih dari cukup untuk digunakan dari aneka macam program kepentingan. Gambar 1 memperlihatkan tampilan awal dari Canva.

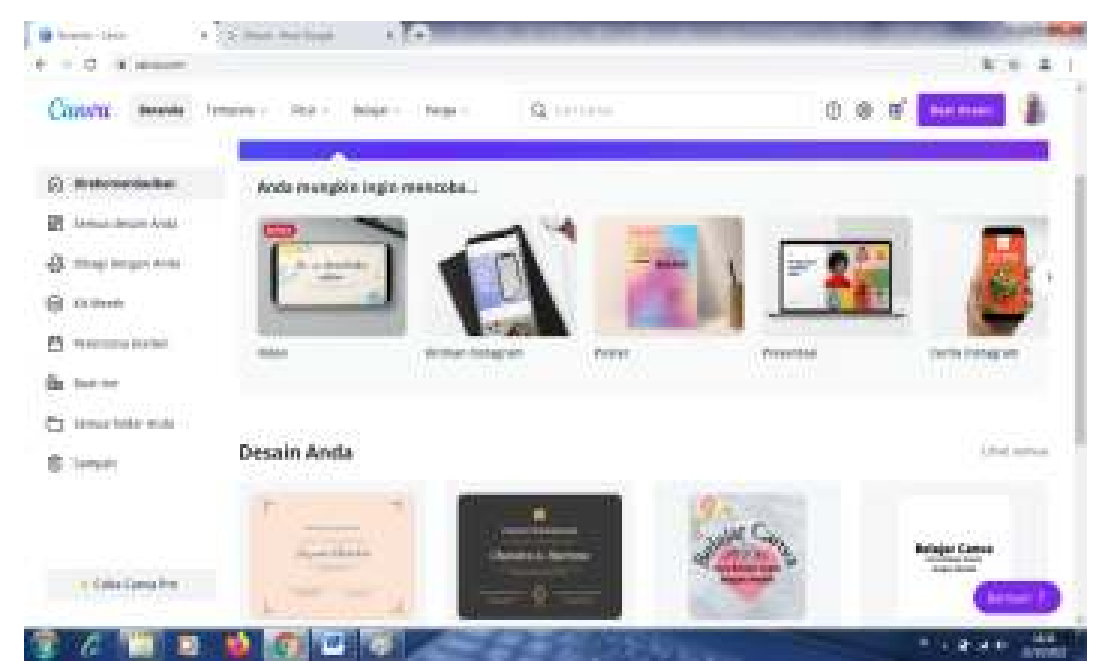

Gambar 1. Tampilan awal Canva

b. Bentuk Desain

Aplikasi Canva memungkinkan pengguna bisa memakai desain pada bentuk apapun, misalnya pada gambar 2 terdapat bentuk pembuatan video, kiriman instagram, poster, 
presentasi, cerita instagram, logo, kisah anda, daftar riwayat hidup, sertifikat, serta lain sebagainya.

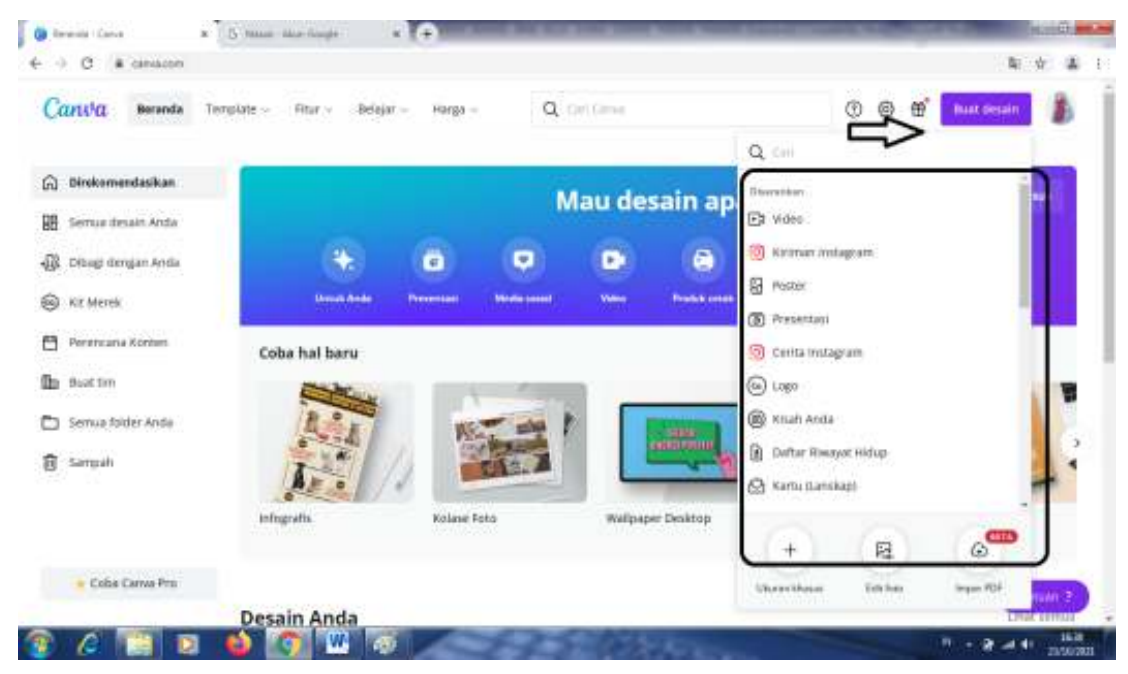

Gambar 2. Bentuk desain Canva

c. Pilihan Bentuk Kata dan Warna pada Desain

Canva juga mampu menghasilkan bentuk desain poster, seperti contoh poster pada gambar 3 tentang anjing yang hilang. Di samping poster ada aneka macam bentuk atau aneka macam alat desain yang bisa dijadikan patokan atau panduan dalam menghasilkan desain poster.

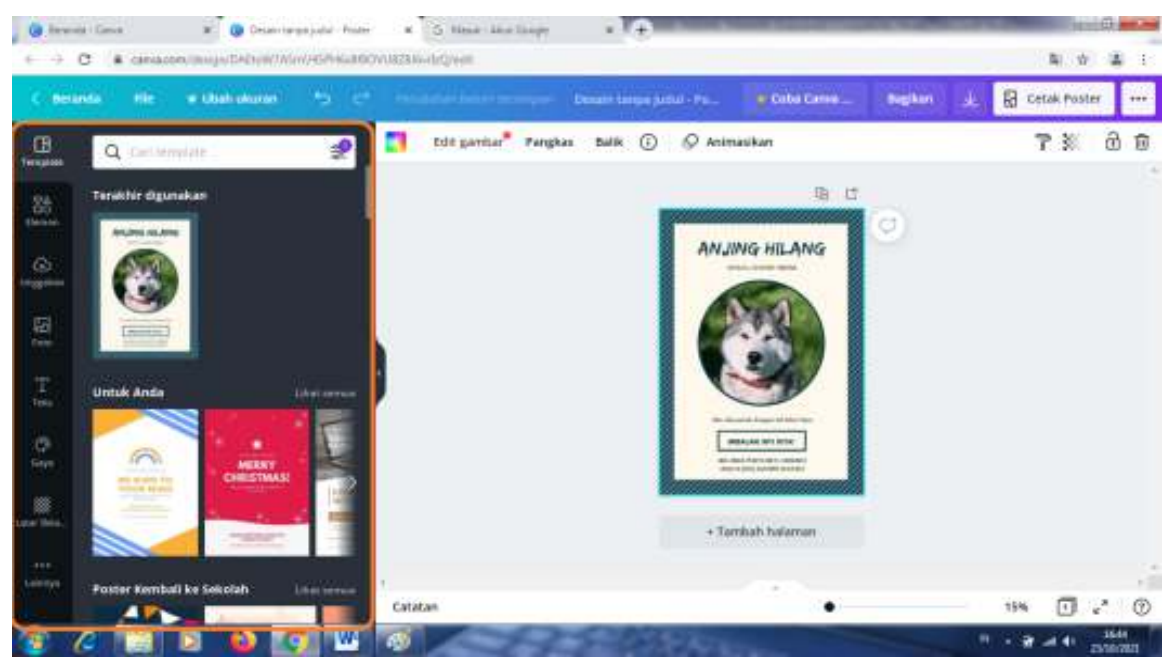

Gambar 3. Macam macan pilihan bentuk huruf dan warna desain

d. Elemen

Elemen pada desain ini aneka macam bentuk, terdapat aneka macam macam elemen yg bisa digunakan, misalnya seperti pada gambar 4 terdapat gambar bunga, atau aneka macam bentuk bulatan, petak, segitiga, segi lima dan segi enam, ada juga aneka macam bentuk 
gambar animasi seperti gambar anjing, karena kita menggunakan anjing menjadi model, maka gambar anjing kita buat di pencarian Canva tadi.

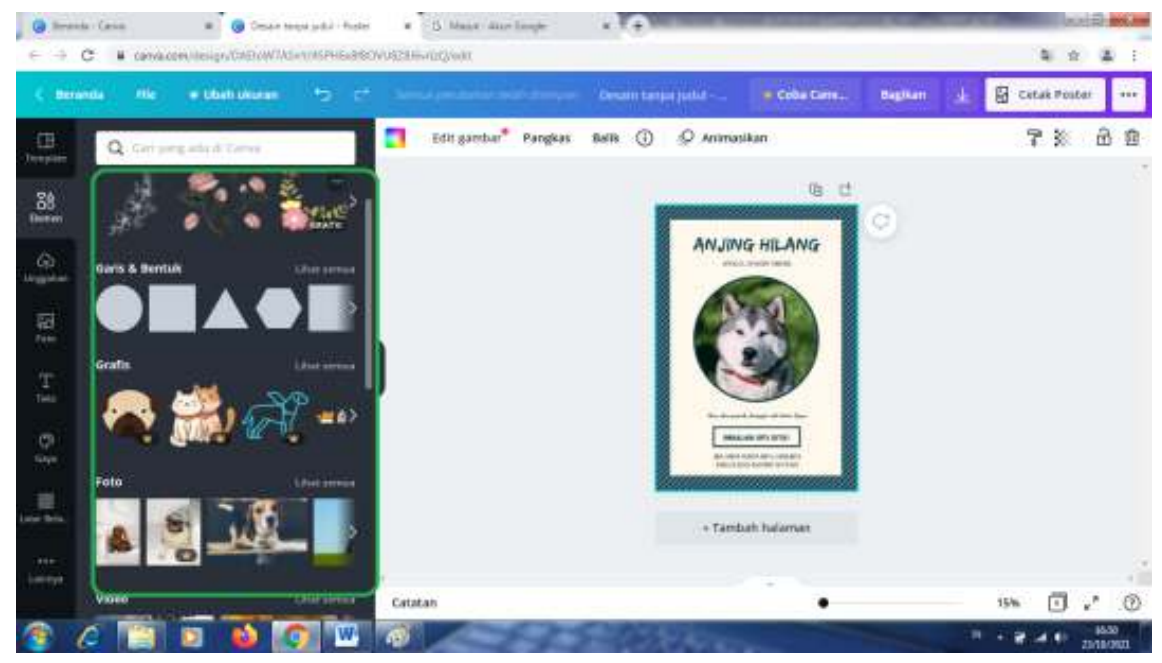

Gambar 4. Elemen dalam Desain Poster

e. Save atau Unduh

Canva juga menyediakan fitur untuk menyimpan hasil dari poster yang telah dibuat tersebut, dan pengguna dapat mengubahnya atau menyimpan pada bentuk PDF, JPG, PNG, Video Mp4 dan Gift, serta dapat mengatur ukuran nya serta kulitasnya. Gambar 5 menampilkan fitur save atau unduh tersebut.

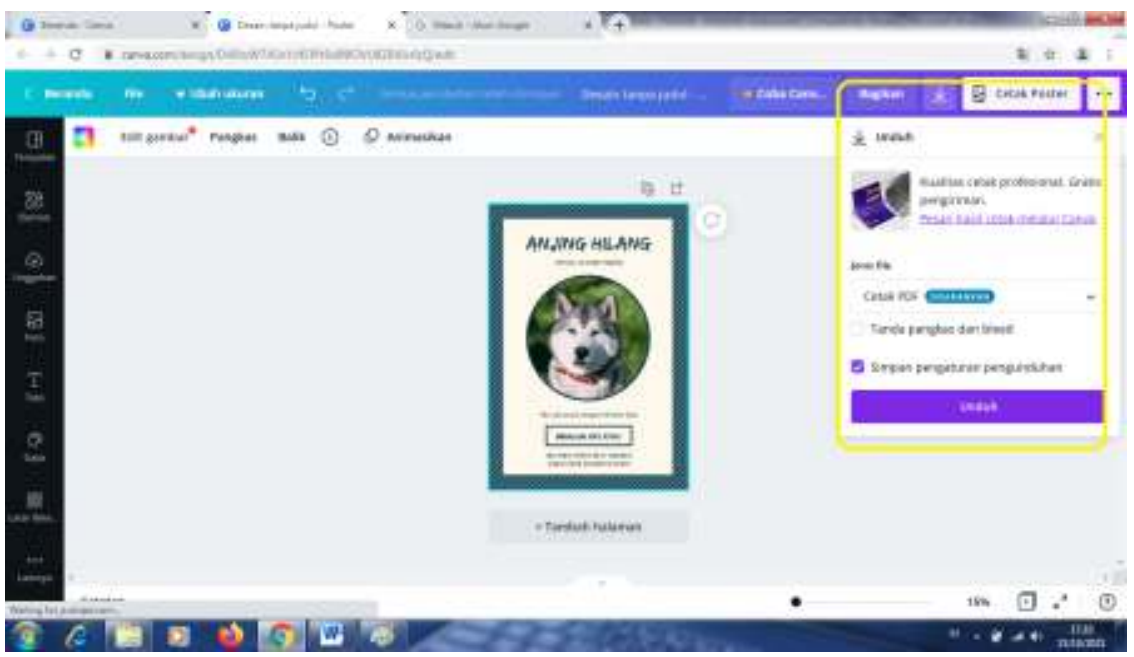

Gambar 5. Save atau Unduh 


\section{f. Hasil Poster}

Gambar 6 menampilkan contoh hasil poster yang dibuat dengan memakai software Canva. Dikarenakan uji coba pembuatan poster mengambil judul artikel menggunakan bahasa Arab, maka pengguna dapat mengganti hurufnya dengan memakai bahasa Arab, seperti itulah hasil huruf yang memakai Bahasa Arab.

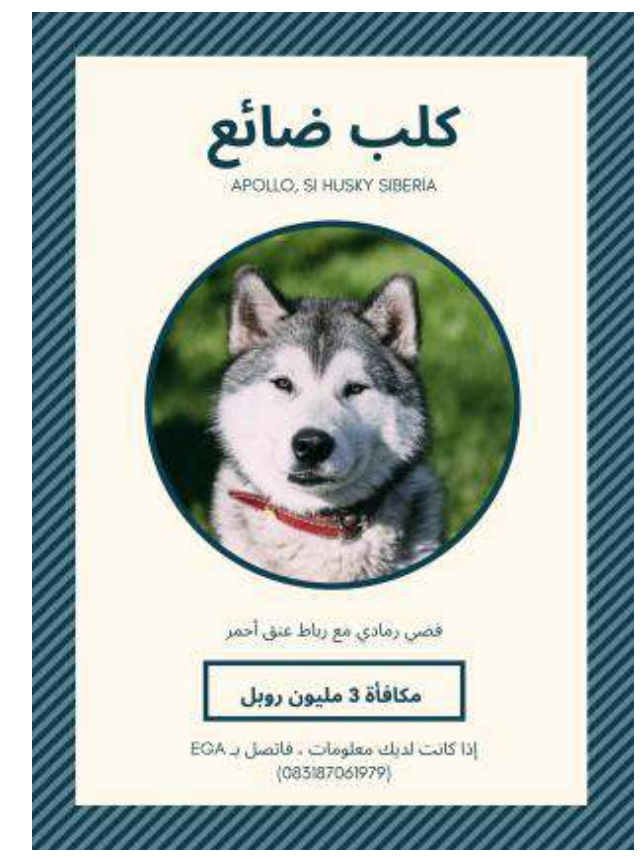

Gambar 6. Hasil Poster Menggunakan Canva

\section{Manfaat dari Desain Grafis menggunakan Canva dalam Bidang Pendidikan}

Hasil penelitian tentang penggunaan Canva dalam pembelajaran bahasa Arab disimpulkan bahwa Canva mengajarkan tentang pembuatan desain grafis untuk pembelajaran. Pendidikan, khususnya peserta didik dapat menjadikan desain grafis ini sebuah media untuk mengembangkan imajinasi dan kreatifitas ataupun menjadikan desain grafis ini sebuah media untuk menyampaikan pendapat dengan menarik. Dengan desain grafis ini sebagai media penyampaian pesan serta bisa menyempurnakan pesan yang disampaikan. Berbagai manfaat disampaikan guru bahasa Arab MAN Padang Panjang. Berikut merupakan kesimpulan dari hasil penelitian atas manfaat desain grafis di bidang pendidikan ditinjau dari berbagai segi, yaitu:

a. Meningkatkan kecepatan proses belajar mengajar dengan cara menyajikan pelajaran dalam bentuk presentasi yang telah di desain dengan memakai Canva. 
b. Memperkenalkan dunia desain pada para peserta didik sehingga peserta didik bisa memahami cara penggunaan software Canva.

c. Memperkenalkan peserta didik terhadap software software yg berada pada Canva.

d. Mempersiapkan peserta didik agar bisa memudahkan menyampaikan pesan pesan pada bentuk desain grafis.

\section{E. Kesimpulan}

Proses belajar tidak terlepas dari kiprah media didalamnya, dikarenakan media pembelajaran ialah suatu bagian dari integral proses pendidikan di sekolah. Kedudukan media pengajaran ada pada komponen pembelajaran menjadi salah satu upaya untuk membantu pendidik dalam berinteraksi dengan peserta didiknya serta lingkungan di sekitarnya. Tujuan penggunaan media software Canva dalam pembelajaran Bahasa Arab untuk penguasaan bahasa dalam berbicara bahasa arab secara baik dan benar serta mampu mengemukakan ide ide cemerlang yang bisa menghasilkan karya yang gemilang di lingkungan sekitar dan bisa pula di manfaat kan bagi lingkungan di dalamnya. Peningkatan motivasi belajar bahasa arab bagi peserta didik dengan menggunakan software Canva ini dapat di terangkat oleh pendidik secara langsung maupun melalui tutorial video yang bisa dipahami oleh peserta didik. Dengan menggunakan media tersebut, peserta didik jadi lebih cepat paham terhadap materi yang sudah dijelaskan, walaupun seorang pendidik tadi tidak menerangkan nya secara langsung atau tatap muka, namun peserta didik bisa memahami materinya dengan cepat, selain itu dengan software ini bisa memudahkan pendidik dalam membuat imajinasi dengan ide ide secara luas tanpa mengganggu aktifitas di sekitarnya.

\section{Daftar Rujukan}

Adipura, B. (2012). "Pengaruh Model Pembelajaran Sains-Teknologi-Masyarakat Dalam Meningkatkan Literasi Sains Dan Teknologi Ditinjau Dari Gaya Kognitif Siswa." AITadzkiyyah: Jurnal Pendidikan Islam 8: 75-83.

Aghni, Rizqi Ilyasa. (2018). "Fungsi Dan Jenis Media Pembelajaran Dalam Pembelajaran Akuntansi." Jurnal Pendidikan Akuntansi Indonesia 16, no. 1. https://doi.org/10.21831/jpai.v16i1.20173.

Hanafy, Muh. Sain. (2014). “Konsep Belajar Dan Pembelajaran.” Lentera Pendidikan : Jurnal Ilmu Tarbiyah Dan Keguruan 17, no. 1: 66-79. https://doi.org/10.24252/lp.2014v17n1a5.

Hanifah Salsabila, Unik, Lailli Irna Sari, Khusna Haibati Lathif, Ayu Puji Lestari, and Asyharinur Ayuning. (2020). "Peran Teknologi Dalam Pembelajaran Di Masa Pandemi Covid-19." AlMutharahah: Jurnal Penelitian Dan Kajian Sosial Keagamaan 17, no. 2: 188-98. https://doi.org/10.46781/al-mutharahah.v17i2.138. 
Herliandry, Luh Devi, Nurhasanah Nurhasanah, Maria Enjelina Suban, and Heru Kuswanto. (2020). "Pembelajaran Pada Masa Pandemi Covid-19." JTP-Jurnal Teknologi Pendidikan 22, no. 1: 65-70.

Hijrah, Lailatul, Muhammad Fikry Arransyah, Khanaya Putri, Novia Arija, and Rini Kurniawati Putri. (2021). "Pelatihan Penggunaan Canva Bagi Siswa Di Samarinda" 3, no. 1: 98-106.

Husna, Mardiatun. (2021). "PENGEMBANGAN MEDIA PEMBELAJARAN AUDIO VISUAL BERBASIS MACROMEDIA FLASH 8 . 0 PADA MATERI SISTEM GERAK MANUSIA DI MTsS." Fakultas Tarbiyah Dan Keguruan Universitas Islam Negeri Ar-Raniry Darussalam,Banda Aceh, , 141.

Izzatunnisa, Lita, Ade Suryanda, Anisa Siti Kholifah, Cynthia Loka, Peralihan Pertiwi Idea Goesvita, Priscila Sindy Aghata, and Salwa Anggraeni. (2021). "Motivasi Belajar Siswa Selama Pandemi Dalam Proses Belajar Dari Rumah." Jurnal Pendidikan 9, no. 2: 7-14.

Komalasari, Yuli, Muhammad Muharrom, and Achmad Sumbaryadi. (2021). "Pemanfaatan Aplikasi Canva Untuk Meningkatkan Fungsionalitas Media Sosial Pada Pengurus Dan Anggota Karang Taruna Kel . Kebon Bawang" 1: 71-77.

Lestari, Sudarsri. (2018). "Peran Teknologi Dalam Pendidikan Di Era Globalisasi." Edureligia; Jurnal Pendidikan Agama Islam 2, no. 2: 94-100. https://doi.org/10.33650/edureligia.v2i2.459.

Miftah, M. (2013). "Fungsi, Dan Peran Media Pembelajaran Sebagai Upaya Peningkatan Kemampuan Belajar Siswa." Kwangsan: Jurnal Teknologi Pendidikan 1, no. 2: 95. https://doi.org/10.31800/jtp.kw.v1n2.p95--105.

Mila, Nur, Andi Naila Quin Azisah Alisyahbana, Nur Arisah, and Muhammad Hasan. (2021). "Efektivitas Pemanfaatan Canva Sebagai Media Pembelajaran Daring." Prosiding Penelitian Pendidikan Dan Pengabdian 2021 1, no. 1: 181-88.

Mugirah. (2002). "Upaya Peningkatan Kualitas Pembelaiaran Di Sekolah Dasar." Jurnal Ilmiah Guru Caraka Olah Pikir Edukatif 6, no. 01.

Mujianto, Haryadi. (2019). "Pemanfaatan Youtube Sebagai Media Ajar Dalam Meningkatkan Minat Dan Motivasi Belajar.” Jurnal Komunikasi Hasil Pemikiran Dan Penelitian 5, no. 1: 135-59.

Munir. (2020). Multimedia Konsep \& Aplikasi Dalam Pendidikan. Antimicrobial Agents and Chemotherapy. Vol. 58.

Muradi, Ahmad. (2011). Bahasa Arab Dan Pembelajarannya Ditinjau Dari Berbagai Aspek. PUSTAKA PRISMA,.

Ngafifi, Muhamad. (2014). "Kemajuan Teknologi Dan Pola Hidup Manusia Dalam Perspektif Sosial Budaya." Jurnal Pembangunan Pendidikan: Fondasi Dan Aplikasi 2, no. 1: 33-47. https://doi.org/10.21831/jppfa.v2i1.2616.

Nurul, Hesti Khuzaimah Yusufiyah. (2021). "Definisi, Tujuan, Dan Manfaat Desain Grafis 1." Defenisi,Tujuan Dan Manfaat Desain Grafis, 6.

Pelangi, Garris. (2020). "Pemanfaatan Aplikasi Canva Sebagai Media Pembelajaran Bahasa Dan Sastra Indonesia Jenjang SMA/MA." Jurnal Sasindo UNPAM 8, no. 2: 79-96. 
Pera Aprizal, Ambo. (2021). "Urgensi Pembelajaran Bahasa Arab Dalam Pendidikan Islam." Jurnal Pendidikan Guru 2, no. 2: 39-56. https://doi.org/10.47783/jurpendigu.v2i2.232.

Rahmatullah, Rahmatullah, Inanna Inanna, and Andi Tenri Ampa. (2020). "Media Pembelajaran Audio Visual Berbasis Aplikasi Canva." Jurnal Pendidikan Ekonomi Undiksha 12, no. 2: 31727.

Rosali, Ely Satiyasih. (2020). "Aktifitas Pembelajaran Daring Pada Masa Pandemi Covid-19 Di Jurusan Pendidikan Geografi Universitas Siliwangi Tasikmalaya." Geography Science Education Journal (GEOSEE) 1, no. 1: 21-30.

Sanwil, Teuku, Rizka Utami, Riyan Hidayat, Dasep Bayu Ahyar, Syarifah Rahmi, Evi Muzaiyidah Bukhori, Suci Ramadhanti Febriani, Dwi Khoirotun Nisa, Nyak Mustakim, and Akhmad Aufa Syukron. (2021). Pembelajaran Bahasa Arab Untuk Siswa SD/MI. Yayasan Penerbit Muhammad Zaini.

Sholeh, Muhammad, Rr. Yuliana Rachmawati, and Erma Susanti. (2020). "Penggunaan Aplikasi Canva Untuk Membuat Konten Gambar Pada Media Sosial Sebagai Upaya Mempromosikan Hasil Produk Ukm." SELAPARANG Jurnal Pengabdian Masyarakat Berkemajuan 4, no. 1: 430. https://doi.org/10.31764/jpmb.v4i1.2983.

Suminar, Dewi. (2019). "Penerapan Teknologi Sebagai Media Pembelajaran Pada Mata Pelajaran Sosiologi." Prosiding Seminar Nasional Pendidikan FKIP 2, no. 1: 774-83.

Susanto, Heri, and Helmi Akmal. (2019). Media Pembelajaran Sejarah Era Teknologi Informasi (Konsep Dasar, Prinsi Aplikatif, Dan Perancangannya). FKIP Universitas Lambung Mangkurat,.

Takdir, Takdir. (2020). "Problematika Pembelajaran Bahasa Arab.” Jurnal Naskhi: Jurnal Kajian Pendidikan Dan Bahasa Arab 2, no. 1: 40-58. https://doi.org/10.47435/naskhi.v2i1.290.

Tanjung, Rahma Elvira, and Delsina Faiza. (2019). "Canva Sebagai Media Pembelajaran Pada Mata Pelajaran Dasar Listrik Dan Elektronika." VoteTEKNIKA: Jurnal Vocational Teknik Elektronika Dan Informatika 7, no. 2: 79-85. 